narmere vurdering af den. Lidt rådes der bod på disse mangler i nummerets "Dokument". Vi gengiver "Udviklingsplan for Danmarks Radio 1984-87".

Udover artikleme om provinsafdelingen og regionalradioerne finder man i dette nummer en artikel om reklamer af Dominique Bouchet: "Reklamen som samfundets spejl". Udgangspunktet er en kritisk gennemgang af Preben Sepstrups introduktionsbog Om reklame, men artiklens intention er at foretage en $\mathrm{i}$ forhold til Sepstrup selvstandig analyse af reklamen som institution.

Tilsidst i nummeret finder man en debatafdeling. Vi har fra Peben Sepstrup modtaget to diskussionsindlæg til artikler i Massekultur \& Medier nr. 6. Det er redaktionens politik, at lade de kritiserende komme til orde med korte svar i samine nummer, og både Steen Buhl og Flemming Hansen og Áge Edvardsen og Lars Qvortrup svarer med korte replikker.

Ved afslutningen af 2. årgang er der sket en udskiftning i redaktionen. Ole Prehn er efter eget фnske udtradt og er blevet erstattet med Aage Erhardtsen og Keld Vorup Sørensen. Vi vil gerne takke Ole Prehn for hans indsats ved opbygningen af dette tidsskrift og byde de nye medlemmer velkomne.

\title{
RETTELSE
}

I Massekultur \& Medier nr. 6 var der sket en fejl $\mathrm{i}$ indholdsfortegnelsen. Som det fremgik af selve artiklen var forfatterne til "Telematikken og dialektikken og kritikken af kritikken" Age Edvarsen og Lars Qvortrup (og ikke Age Erhardtsen og Lars Qvortrup). Vi beklager. 


\section{PROFESSIONEL FOLKELIGHED \\ - OM "LANDET RUNDT" OG "DAGENS DANMARK"}

\section{Af Per Jauert, Jan Mølgaard, Mogens Schmidt og Keld Vorup Sørensen}

\section{Et hus et sted il landet}

Der skal frækhed til at placere en sådan mastodont midt på åben mark i Rindals fødeland. Men nu ligger det der, Provinsafdelingens nye hjem, som et grundmuret udsagn om, at folkets forlystelse betragtes som en alvorlig sag. Her er intet overladt til tilfældighederne. Komplekset rejser sig fra toppen af den gamle galgebakke nord for Århus, komplet med stenvolde, valdige flader i rust, glas og beton. Et højst ufremkommeligt brombærkrat erstatter en voldgrav omkring det $i$ $\emptyset$ vrigt borgagtige anlæg. Man kan neppe gøre indtrykket af helheden op på anden vis: her står man overfor et kunstværk, en gigantisk bygningsskulptur, der hviler helt og udelukkende i sig selv. Et egentligt stofskifte med de nære landskabelige omgivelser er det vanskeligt at fåje p̊̊. Ganske vist laner det lave byggeri et vist højdeformat af selve det enorme rum omkring bakken. Alligevel er det vanskeligt at frigфre sig fra den kætterske tanke, at det kunne have ligget hvorsomhelst på danmarkskortet, også i hjertet af København, for det er sig selv nok. Et stykke abstrakt funktionalisme, der tilraner sig landskabsindtrykket. Samtidig udstråler det hele registeret af impulser, som enhver provinsbo efterhånden har lart sig at bestemme som udslag af velfardsteknokraternes nye magtfuldkommenhed. Der blev jo heller ikke rystet på hånden, da enhver storre provinsby fik sit nye rådhuspalads $\mathrm{i} \phi \emptyset l v a n d e t$ på kommunalreformen.

Ingen ved sine fulde fem ventede vel at finde Provinsafdelingen gemt bag stokroser og bindingsverk; men springet til dette er enormt. Der må vare en tredje vej. Når den ikke er benyttet, må forklaringen være, at huset på galgebakken er blevet til i hjerner, der ikke udelt har varet optaget af, hvordan man bedst trak de levende provinser ind i rampelyset på deres egne vilkår. 


\section{Et hus til at vokse i}

Nu er det hфjst en gammel nyhed, at Provinsafdelingen har faet et hus, som er til at vokse i. Faktisk har afdelingen selv aldrig lagt skjul p\&, den ønsker, at det er hér et dansk TV 2 skal have sin base, hvis det gar,, som den selv og de borgerlige krafter i og omkring Radioradet vil. Tanken var fremme allerede i 1972, mens Provinsafdelingen endnu var p\& tegnebrettet, dengang fort til torvs af bl.a. Bernhard Baunsgaard. Siden har den svevet lavt over enhver diskussion, der havde Provinsafdelingen som tema, og det har varet mange. For Provinsafdelingen har fra sin fødsel varet et af de helt store erobringsmal i den kulturkamp, der till stadighed f $\phi$ res i dette land mellem de borgerlige partier og deres satellitorganisationer pa den ene front og Socialdemokratiet på den anden. Og i lyset heraf giver byggeriet i Halmstadgade maske mening. Det står som et, af gode grunde noget uklart, monument over en hidtil uafgjort kamp, hvor provinsen er slagmark, men hvor dét, kampen gæider, reelt er TV-monopolets fremtidige skabne i Danmark og med dette den fri eller indskrankede ret til sjalefiskeri fra allerhojeste plan.

Da TV 2's og Provinsafdelingens fremtid saledes synes at vare blevet to sider af samme sag - bl.a. fordi man nappe lader den overskydende kapaciset i Halmstadgade ruste op selv i sparetider som disse - sa var det maske på tide at spørge: Hvordan er det kommet så vidt? Det er trods alt ingen naturlov, at provinsen blot skal gøre det ud for et belejligt trappetrin i opstigningen mod TV 2. Hvorfor tog udviklingen denne retning?

\section{Provinsen ind fra kulden}

Ubalance mellem hovedstad og provinser er et gammelkendt problem, ogsa i Danmark. Ofte har det givet sig pragnante udslag i f.eks. den politiske historie. I 1967, hvor tanken om en decentralisering af DR for alvor fik male via et radiokommissionsarbejde, havde skavheden dog nappe nogen alt for fast plads pa offentlighedens dagsorden. Det var højkonjunktur - ogs\& i de narmest f $\phi$ lgende år og ikke mindst provinsen markede følgerne heraf. Statsapparatet og den offentlige sektor I almindelighed skød knopper netop derude, hvor før kun kragerne vendte. Universitetscentre, centralsygehuse, nye gymnasier, motorveje, kommunelorvalt- 
ningernes centralpaladser $0 . \mathrm{m} . \mathrm{m}$. taler deres eget sprog om, at provinsen var taget til hovedstadens og centralmagtens nåde $i$ et $\emptyset \mathrm{mt}$ favn- eller kvalertag. Før eller siden måtte turen komme også til DR.

\section{Var hastvark lastvark?}

DRs Provinsafdeling, der kom på fødderne I april 1973 som fors $\emptyset$, var på ingen måde et barn af et massivt folkekrav. St $\emptyset$ det til afdelingens oprettelse kom indefra og oppefra i den centrale forvaltning dvs. fra kræfter i DR, som gerne så en ekspansion og fra Radiorådets politisk valgte medlemmer. Det kan lyde bagklogt og hult, men spørgsmålet er i dag, om det hastværk, der greb Radioradet, da det i 1971/72. ikke blot konfirmerede, men langt overtrumfede de forestillinger, radiokommissionen havde gjort sig om en rent geografisk decentraliseing af DRs virksomhed, ikke fik helt afgørende indflydelse på den udviklingslinje, Provinsafdelingen fik at bevage sig ad? Når modspillet fra provinsen ikke forefandtes i aktiv form; når det samtidig var helt åbenlyst, at provinsen som programpolitisk tankesæt I DR endnu på dette tidspunkt var et hul, som ingen kendte præcise midler til at udfylde med det første, så havde en vis tilbageholdenhed næppe været en unødig luksus. Men det hører med i billedet af DRs situation, dengang som nu, at institutionen til stadighed er valplads for det partipolitiske håndgemæng. Og håndgemænget fik i 1972, hvor principbeslutningen om afdelingens oprettelse blev truffet, det udfald, at man bevilgede sig selv endnu en arena, hvor kampen kunne gå videre.

\section{Fronteme trakkes op}

Sagen var, at såvel Socialdemokratiet som de borgerlige, ikke mindst Venstre, havde kulturel decentralisering som fast punkt på partiprogrammet. Da det var opgangstider, var ekspansion mulig. Den var ogsa efterspurgt, nemlig blandt DRs egne folk, som kunne påpege rimeligt begrundede kapacitetsproblemer, og striden kom da heller ikke længe til at stå orn, hvorvidt man skulle udbygge i provinsen eller ej, men om hvilken form man skulle valge at decentralisere $\mathrm{i}$. 
Fronterne så nogenlunde săledes ud:

Danmarks Radio har - I borgerlige kredse - altid været betragtet som en af Socialdemokratiets største historisk-kulturelle erobringer, et indtil 1973 helt uindtageligt fort, hvorfra partiet med de mest moderne og effektive medievåben kunne bestryge det ganske samfund. At der var - og til dels stadig er - bund i denne opfattelse, bekræfter Socialdemokratiet jæunligt selv, når der kæmpes om kontrollen over mastodonten i hovedstaden. Ringmuren omkring fortet er DRs monopol på radio- og TV-virksomhed i Danmark, og denne mur havde de liberale eller borgerlige indtil 1973 hyppigt løbet panden forgæeves imod.

\section{Decentraliseringen som kulturpolitisk chance}

Decentraliseringstankerne var derfor en oplagt mulighed for de borgerlige partier. Deres mediepolitik er som den $\emptyset$ vrige politik på partiprogrammerne funderet i forestillingerne om det frie initiativ og den frie konkurrence. At et privatkapitalistisk organiseret alternativ til DR måtte være det langsigtede mål, var soleklart. Men da det ikke kunne indfries umiddelbart, måtte man oprette et mere realistisk sigtepunkt. På kort sigt kunne man forsøge at tiltvinge sig større indflydelse på DRs programmer og specielt deres indhold via nyskabelsen. Det kunne ske ved, at man strategisk udnyttede den kulturelle overvagt, man besad i provinsen. Denne overvægt, hvis hjørnestene er den borgerlige provinspresse, et solidt greb om amtslige og kommunale forvaltninger udenfor de allerstørste byer samt et solidt stemmemassigt forspring i de fleste provinsregioner, skulle blot forbindes med en offensiv, der 1 offentligheden kunne skabe klangbund for, at den decentraliserede del af DRs programvirksomhed blev underlagt de lokale politiske magtcentre og ikke DR, København. Dette forehavende gjorde Venstre sig til primus motor i.

Socialdemokratiet så naturligt nok med betankelighed på disse ideer. Ganske vist var tanken om kulturel decentralisering en gammel mærkesag på programmet; men partiet matte direkte frygte den sammenkadning af kulturel overvægt og politisk programkontrol på provinsfronten, som de borgerlige kampede for, bl.a. fordi det i disse år blev indlysende for enhver, at den socialdemokratiske provinspresse var forvandlet til en ruinhob. Partiets muligheder for at yde kvalificeret modspil $\mathrm{pa}$ sådanne lokalpolitiske vilkăr var derfor kun ringe. Socialdemokratiet måtte betinge 
sig en fortsat klar myndighedsforbindelse mellem den påtankte provinsafdeling og ophavet i Gyngemosen. Opgaven blev derfor, logisk nok, defensiv. Man måtte bremse op overfor den outrerede decentraliseringsform, de borgerlige i øjeblikkets interesse lagde op til. Der skulle decentraliseres, men under kontrol...

\section{Stridens kerne og udfald}

Det afgørende stridsspørgsmål i Radiorådet 11972 blev derfor: Hvor $1 \emptyset$ s eller fast bør forbindelsen mellem det nye provinsforetagende og den gamle DR-pyramide være, når nu Socialdemokratiet har lagt sig fast på, at decentraliseringen - på den ene eller den anden vis - skal foreg̊̊ indenfor denne? Enden på denne tvist, der blev ret bitter, blev beslutningen af 1972 om, at DRs Provinsafdeling skulle have en organisatorisk og styringsmæessig særstatus.

Afdelingen kom til at sortere direkte under programdirektøren, løsrevet fra de andre københavnske afdelinger. Saledes var provinsafdelingen også i den unikke situation, at den kunne producere programmer indenfor alle områder, at den både kunne lave radio og $t v$, og at den var tværgąende organiseret $i$ forhold til de forskellige faggrupper. Altså en blфdere organisationsmodel, der skulle kunne fremme fors $\emptyset \mathrm{g}$ og spændende nye initiativer. Kun regionalradioerne blev trukket lidt ud fra Aarhusafdelingen - produktionen blev opdelt i otte distrikter, spredt over hele landet.

Formelt var der tale om et kompromis. Historien skulle dog vise, at de borgerlige havde trukket det længste strå. Den kulturelle overvægt, disse kræf ter havde og stadig har i den etablerede provins, kan i læengden ikke overdøves i et politisk system, der bygger på et repræsentativt princip. Og den faktiske selvstæendighed, der på trods af massiv modstand fra ledelse og medarbejdere I DR, København var tildelt provinschefen, var guld verd for den rette mand. Og denne mand fandt man. Hans navn er Gerhard Nielsen. 


\section{Syv år med Provinsafdelingen}

Med den sarstatus, Provinsafdelingen altså fik, stod en trojansk hest pludseligt bag DRs ringmur. Af de to institutioner kunne vokse fra hinanden med tiden var ikke blot en mulighed. Det var snarere en forpligtelse, der ville være fulgt med en hvilken som helst person på topposten i Århus. De markante udviklingsmuligheder, afdelingen havde - i hvert fald umiddelbart efter 1973 - la jo sa at sige bundet i det borgerlige politiske bagland. Det var her og ikke i driftsledelsen, der skulle hentes støtte, hvis den yderlige position, afdelingen stod pa, ikke blot skulle befæstes, men også udvides! Stod der således "provins" i positiv på arbejdssedlen, anede man dog allerede fra starten ordene "borgerligt radio og TV" i negativ. Det, de borgerlige politikere ønskede, var jo en klart markeret modvægt mod DR, København - et permanent og levedygtigt kulturpolitisk alternativ, som lod sig f $\emptyset$ re frem oppefra.

Gerhard Nielsens opgave var således klar nok. Han skulle langsomt, men sikkert lirke monopolets $d \emptyset \mathrm{r}$ på klem og provinsen skulle herunder fungere som håndtag. Denne opgave har han udført konsekvent og loyalt - omend ikke altid ganske lydløst - og tilsyneladende uden ringeste mistanke om, at provinsopgaven og et TV 2 kunne være andet og mere end slet og ret samme sag. Resultatet er blevet en institution, hvis grove omrids i dag kunne beskrives nogenlunde således:

\section{Lav-pris TV}

Afdelingen i A rhus er i driftsmæssig henseende bevidst organiseret som et lavprisforetagende, hvor man $i$ langt højere grad, end det har været tradtition tidligere I DR, fors $\phi$ ger at indrette sig efter almindeligt virksomhedsm $\emptyset$ nster. Der satses hårdt pa (mer-) produktivitet hos medarbejderne, bekæmpelse af administrations- og fagforeningsvælde samt en management-stil, hvis forbilleder endnu diskuteres i handelshøjskolernes lærebøger. Essensen heraf er at virksomheden endnu er så overskuelig $\mathrm{i}$ omfang og opgaver, at afdelingschefen virkningsfuldt har kunnet opbygge sig en personlig og eksklusiv kompetence pa -helt bogstaveligt ethvert niveau i foretagendet fra praktisk udsendelsestilrettelæggelse over sæsonplaner og til ansæettelses- og фkonomispørgsmål. Arbejdet ledes og fordeles på en måde, som er egnet til at give respekt, selv $\mathrm{i}$ arbejdsgiverkredse. 
Udsendelsespolitisk har man i Provinsafdelingen arrangeret sig saledes, at man klart og utvetydigt skiller sig ud fra Gyngemosen, selv om man endnu må kxmpe om plads på samme kanal.

For det første har man - som en abent erklaret hensigt-stillet sig det uglesete erhvervsliv og dets ledere og politiske sympatisprer naer, vel vidende, at denne håndaste respekt for borgerlige primarinteresser ikke ville blive overset på rette sted, nemlig i baglandet.

For det andet har man sat sig for, at alle produkter fra afdelingens varksteder skal udstrale en anden kulturpolitisk grundholdning end den, man normalt identificerer DR, København med. Varemarket er den såkaldte "positive journalistik". Angiveligt og if provinsens indre liv. Mindre lyrisk, men med større føje, kan det dog havdes, at dens rette ophav snarere er den type journalistik, der hver uge salger Billed Bladet og Familie-Joumalen. Man indretter sig bredt populistisk, dvs, udgranser sprangfarlige, kontroversielle, ikke-stuerene emner og fors $\phi$ ger som helhed "at gi' folk hva' folk vil ha" - hvilket aldrig énsidigt har varet DRs officielle malsatning. Den har stedse varet praget af forestillinger om en oplysningsforpligtelse, der indebar, at man undertiden også strøg hunden mod hårene.

\section{Den laveste fallesnavners princip}

Denne mere end højlydte mumlen til seerskarens konservative bevidsthedslag bares oppe af endnu en velkendt ugebladsteknik: man leverer pr. definition kun udsendelser, som er afspecificerede. Det vil sige udsendelser, som i lige grad og på én gang henvender sig til direktøren, husmoderen og skoleeleven - uden smaligt hensyn til regionale eller andre forskelligheder. Denne selvbegransning til kun at bevage sig langs den laveste fallesnæevner mellem de i $\phi v r i g t$ divergerende seerinteresser kan ikke vare udsprunget af tanken om at bøje det individuelt, lokalt eller provinsielt særegne i neon for seernes bjne. Tvartimod. Under denne synsvinkel falder det saregne ud, det forsvinder ganske enkelt. Derimod er det en glimrende platform for viljer, der spekulerer i, hvordan man udnytter store seertal og formel popularitet $i$ andet $\phi j e m e d$. 


\section{Provinsen i baggrunden}

Provinsafdelingen har stedse, men nok i tiltagende grad underlagt sig en ekspansionstænkning, som helt og holdent strømliner det udviklingsarbejde man iværksætter, Målet er et TV 2 i Århus. Den indlysende praktiske konsekvens heraf er, at man énsidigt satser $p \AA$ at vokse op i højde med DR, København, teknisk og popularitetsmæssigt, så man en dag kan gå sine egne veje. Dette tager firs procent af ilten i institutionen og bestemmer til enhver tid strategien. Den lægges nemlig efter, hvor "fjenden" i $\emptyset$ jeblikket er svagest, og hvor man som en følge heraf lettest kan gøre strandhugst. Derfor står der børne- og ungdomsprogrammer og underholdningsprogrammer på spisesedlen i Halmstadgade netop nu. Køllen svinges mod de steder, hvor konkurrenten allerede har fået sine sår af "kunderne" eller pressen.

Mens dette pågår, mens ekspansionen drives fremad til akkompagnement af borgerlige piber og trommer i Radiorådet, bliver det dag for dag klarere, at provinsen er reduceret til rent alibi eller skalkeskjul for en simpel medie- og kulturimperialistisk hensigt. Det vidner udviklingen i bl.a. mandagens TV-programmer om.

\section{Provinsafdelingens programflade}

Genremæssigt dækker provinsafdelingen som næunt under én hat de samme områder som de ellers forskellige afdelinger I DR. Her findes underholdningsprogrammer, magasinprogrammer, debatudsendelser, portrætter osv. Men p⿺ trods af en genremæssig traditionalisme har afdelingen alligevel sin egen profil - som ikke blot kan aflæses i programtitler som "Bytinget" og "Mødestedet" -men som isar kendetegnes ved den gennemgående synsvinkel, eller grundtone i programmerne.

Provinsafdelingens udsendelser tager ikke stikkene hjem ved rappe, dybdeborende, konfliktspandte udsendelser, som f.eks. flere af Kanalerne eller Flindt Pedersen og Stephensens features. Nok kan stoffet vare kontroversielt, men konflikterne er sjaldent det centrale, de trækkes aldrig skarpt op. Selv når problemdebatten står i centrum, rummer programmerne harmoniserende eller endog underholdende elementer, der afrunder de skarpe kanter, som mătte vare dukket op undervejs. 
Det program, som tidlligere mest markant udtrykte provinsafdelingens samlede programpolitiske intentioner, var "Landet Rundt". Her var stort set alle genrer repræsenteret - fra underholdning til personportrætter, fra dokumentariske casestories til nostalgiske rundvisninger i idylliserende provinsmiljøer. Her var alt fra problemdebat over information til underholdning.

\section{"Landet Rundt"}

Når man skal karakterisere det sat af faktorer, som tilsammen danner baggrunden for "Landet Rundt", $i$ en årrække provinsafdelingens mest populære produkt, skal man vare sig for at vurdere programmet ud fra TV-byens normer. Sa falder det nemlig uhjæelpeligt igennem. Mens det kørte, var det en stående vits blandt mediefolk, et slags synonym for den specielle danske tv-amatørisme - et nærmest uudtømmeligt fond af groteske bonderøvshistorier, som morede det ganske land lørdag efter lфrdag i "Hov-Hov" og "Uha-Uha". Men om mandagen passerede "Landet Rundt" gang på gang den magiske grænse for succes i DR med seertal på over 2 mill. Det har nok ikke varet på grund af den - set med københavnerøjne ufrivillige komik, som amatørerne "derovre i Arhus" ekcellerede i. Den tilsyneladende uprofessionelle stil havde sine kvaliteter, som åbenbart faldt $\mathrm{i}$ en masse menneskers smag. Men var stilen så amatørmæssig - var den uprofessionel? Måske var der snarere tale om, at provinsafdelingen med dette program var på vej til at udvikle en stil, som var adækvat i forhold til de emner, man фnskede at behandle. En "professionel" stil, som var overensstemmende med det billede af Landet, som provinsafdelingen ønskede at tegne. Eller måske var der også tale om, at afdelingen bl.a. pa grund af de beskedne tekniske ressourcer, blev bragt i kontakt med stoffet p̊̊ en helt anden direkte måde, end det ellers var gængs i DR. At stoffet og brudfladerne i det "Iå fremme på overfladen" og ikke behøvede megen redaktionel bearbejdning.

Hvis svarene på disse spørgsmål er positive, er professionaliseringsbegrebet unægteligt relativeret. Og samtidig kan de tyde pa, at afstanden mellem center og provins ikke er så ringe endda. Men lad os se nærmere på "Landet Rundt" - dets stil og dets indhold. 


\section{Hjemlig hygge}

I "Landet Rundt" var studiet udgangspunkt for strejftogene rundt i landet. Alligevel var det dog aldrig opulent placeret som et forum for alskens udfoldelser med musik, hjørnearrangementer, talerstole og applauderende publikum i udspekulerede kulisser. Studiet var upratentiøst, bevidst langt an pa blot at være det sted, hvor udsendelsens vert var placeret, og hvorfra man blev ledt rundt til de lokaliteter i landet, som redaktionen havde bes $\phi t$ i den forløbne uge. Næsten hver gang havde man inviteret en gast i studiet til et direkte indslag, og vedkommende faldt som regel godt ind $i$ den prunkløse ramme, som var programmets særtræk: en stol til værten, én til gæsten, et sofabord med en buket blomster og en bagvag med neutrale, afstemte farver. Af og til anbragte man ting, som diskret markerede kontakten til naturen, og som angav de skiftende årstider, f.eks. en nyudsprungen bøgegren eller en lille buket vintergækker.

Denne enkle studieopbygning, hvor man ikke fik en fornemmelse af "rum", men snarere af et hjørne af en dagligstue, havde primart to funktioner. For det første markerede den, at tv-sceneriet ikke var det centrale i udsendelsen, at "det vigtige" ikke sker her, men ude i landet. Derfra blev det så hentet hjem og vist frem, som man i stuen viser lysbilleder eller film for sine gaster. Mange af reportageindslagene bar også præg af "smalfilmsæstetik", hvad der i grunden ikke er så mærkeligt, når man tænker på de begrænsede tekniske faciliteter, som var til rådighed for afdelingen og især for meddelernettet, de lokale free-lancere, hvis produkter man på entreprisevis købte ind efter behov.

For det andet markedere den overskuelige og relativt faste studieopbygning bekendthed og fortrolighed. Detaljer kunne forandres, men enkeltheden, det prunkløse i sceneri og prasentationsform var gennemgående år efter år.

Med til dette billede hører også samtaleformen i studiet, der lå fjernt fra f.eks. tvavisens ofte kontante og pointes $\emptyset$ gende journalistik. Preben Heide, Ann Nissen eller Lars Herluf Jensen introducerede 1 almindeligt hverdagssprog de enkelte indslag og hverdagssproget fulgte med, når man havde gaster I studiet. Her var det "snakken", det gjaldt, tit styret af en oprigtig nysgerrighed mere end af en interesse I at præstere "afslørende" eller dybdeborende journalistik over for 
"interview-offeret" som det så afslørende hedder i jargonen. Selv studieværternes nervøsitet blev til et tegn pa deres jordbundethed. De var ikke hovne eller, hvis det kiksede, klodsede som I København, men ligefremme og derfor naturligt påvirkelige af at vare pa fjernsyn.

\section{Den harmoniske provins}

Hver udsendelse startede med en rakke korte filmindslag - en 5-6 stykker af 1-2 minutters varighed, hvor man bestræbte sig p\& at komme rundt $i$ landet, fra Bornholm til Jordjylland. Som regel var der ingen tematiske fællestræk mellem indslagene. De kunne rumme alt mellem himmel og jord: demonstration af vandingsanlæg i Vestjylland, Dybbøl Mølle stopper produktionen, præmiering af sunde børnetænder i Gjern kommune, arkæologiske unders $\emptyset$ gelser i forbindelse med etableringen af naturgasnettet osv.

Isoleret betragtet rummer indslag af denne karakter ikke noget sprængstof, målt med tv-avisens eller københavneravisernes alen. De kan snarere sammenlignes med provinsavisernes lokale petitstof. De vakker interesse, fordi de appellerer til den samme grad af nyfigenhed og ægte interesse for de små tildragelser eller de store omvæltninger, som kan optage sindene i et lokalområde. Det kontroversielle af enhver art holdtes ude fra dette strejftog - intoneringen af programmet var sikker fra gang til gang: alt står vel til, og nu kan man med opladt sind gå videre fra status quo til de lidt langere reportageindslag, som også udviste en geografisk og emnemassig spredning. Hvor de korte filmindslag (speaket fra studiet) langt overvejende var fra landet, bevægede man sig i reportagerne ogsa ind i de større byer. Men størsteparten af indslagene var dog alligevel fra landområderne-landet, landsbyerne og de mindre provinsbyer.

Reportagerne var oftest præget af overskuelighed i billederne. Der var mange "abne" billeder med landskaber, vand og horisont - og her bevægede reporteren sig rundt med mikrofon, gummistøvler, parcacoat og vindblæst hăr. Denne enkelhed og narhed i stilen pragede ogsa ternaerne $i$ den type indslag, som fortalte om den harmoniske provins. Indslagene kunne, ved f.eks. at handle om det menneskelige sammenhold omkring den lokale brugs eller det lokale forsamlingshus, vise, at de 
gamle provinsvardier havde aktuel gyldighed. Ved således at eksemplificere sammenholdet omkring provinslivets institutioner fik man trukket nogle historiske linjer tilbage til det, som var - og som altså stadig eksisterer: fallesskabet i provinsens sociale liv.

Eller emnet kunne være et andet, f.eks. gården, som drives efter før-industrielle principper uden el og moderne maskineri. Her var der ikke tale om provinsen som en truet, men stadig intakt tilstand, men om provinsen som overleveret form - som musealt arvegods, hvor reporteren som en stolt kustode viste os rundt blandt de overleverede sjældenheder.

I indslagene om den harmoniske provins bevægede redaktionen sig i grænseområdet mellem loyal identifikation og idylliserende udlevering. Man tilstræbte en ærlig forståelse for de centrale vardier og kvaliteter i det provinsielle hverdagsliv. Men samtidig blev provinsen anskuet som "det tabte land". Den blev forvandlet til idyl, når man så på den med storbymenneskets troldsplint i фjet.

Men provinsen I "Landet Rundt" var retfærdigvis ikke kun sammenhold og idyl. Det blev også afsløret, at der fandtes problemer og konflikter.

\section{Den disharmoniske provins}

Problemerne blev dog vinklet specielt. I "Landet Rundt" så man sjeldent indslag om egentlige provinsinterne konflikter. Når problemer blev trukket frem og behandlet, faldt de oftest i én af to kategorier.

Der kunne enten være tale om, at den rolige, organiske fremadskriden i provinsens liv blev anfæg tet af problemskabende kræfter, som kom udefra. Disse kunne dog være "nфdvendige", f.eks. af hensyn til produktion eller фkonomi. Da måtte man bøje sig for udviklingen, for fremskridtet og samtidig beklagende konstatere, at noget vardifuldt gik tabt.

Eller der kunne være tale om en intervention, som ikke var rationel eller begrundet - tiltag fra centrene, fra amter og stat, som gik imod rimelighed og fornuft. Her 
udfoldede "Landet Rundt" sin kritiske journalistik, hvor eksperterne blev stillet til regnskab for deres gerninger - og hvor "den lille mand i knibe" kunne udtrykke sin harme uden megen modargumentation. I denne type indslag kom "Landet Rundt" nok tattest på at markere en politisk profil. Hvor man i midten af 1970 'erne kunne registrere et småborgerligt oprør mod statsformynderi, skattetryk og centralisme og hvor registranterne af denne bevagelse svingede mellem vurderinger af fænomenet, som strakte sig fra "højrepopulisme" til "folkeligt oprør" - fulg te "Landet Rundt" fænomenet og bidrog selv til det med en of te tydeligt markeret antibureaukratisk holdning. Man hentede tit de gode historier frem, når man kunne berette om bureaukratiets mere komiske ekcesser - f.eks. var der historien om udlandsdanskeren, som ville forære sin gård væk, men ikke kunne komme til det, fordi ingen officielle instanser kunne blive enige med sig selv eller hinanden om legaliteten i en sådan transaktion.

\section{Modsæetninger og harmoniseringer}

Når den kritiske journalistik på provinsvardiernes præmisser alligevel aldrig fik lov til at blive rendyrket i "Landet Rundt", så hang det for os at se sammen med to forhold. For det første den uklare provinsopfattelse, som programmet blev båret af. P\& den ene side viste det udpræget sans for provinsidentiteten - en loyal indleven $i$ de særlige sociale og menneskelige særtræk, som op gennem historien er blevet udviklet $\mathrm{i}$ organiske mønstre og former. $\mathrm{Pa}$ den anden side var der en tendens til at idyllisere de samme forhold, til at anskue provinsen med den

nostalgiske bybos $\emptyset$ jne, som det tabte land, hvor den sentimentale erindring udviskede konflikter og indre modsætninger. Den kritiske vinkling af problemerne havde altså sine klare grænser. Modstandsformerne kunne refereres og anskueligg bres $\mathrm{i}$ deres konkrete og isolerede udtryk, men bevarings- og kustodeinteressen tillod aldrig den selvkritiske eller provinskritiske dimension at komme til udfoldelse.

For det andet hang begransningerne i den kritiske journalistik sammen med udsendelsesformen. Den stereotype "setting" af programmet var den afgørende faktor i harmoniseringspræget. Når konfrontationstærsklen blev nået, enten ved, at en mulig lфsning krævede politisk organisering eller polit-ideologisk justering, blev focus trukket bort. Sagen blev relativeret eller forsvandt i studieværtens nivelle- 
rende udgangsreplik: - "og nu til noget mere fredeligt/helt andet". Den additive programstrukturering kunne ikke rumme den profilerede konfliktfremstilling.

\section{Fortrolighed og naervar}

$\mathrm{P} \&$ trods af de indre modsætninger i provinsopfattelsen ma udsendelsens succes alligevel tilskrives det tilsyneladende organiske helhedspræg i programmet. Dette helhedspræg kunne det have, fordi det ramte erindringsspor hos så godt som os allesammen. Spor som var truede, og som seerne derfor instinktivt forsvarede.

I 1970 'erne, hvor så mange modsæ tninger mellem center og provins blev tydeligere, svarede "Landet Rundt" p\& usikkerhed, behov og langsler i og uden for provinsen. Behov, som til stadighed drives frem af "udviklingen" - og som i virkeligheden skærpes af TV-mediet dels fordi det er centerstyret i sin organisationsform, dels fordi dets indhold og stil raffineres og zstetiseres. Her var "Landet Rundt" med sin bevidste (og nødtvungne) spillen på amatørismen, med "snakken" og den prunkløse stetik i sig selv en demonstration af de vasentlige kvaliteter ved provinslivet: den gensidige fortrolighed, intimiteten.

Seer-interessen byggede netop på den klare gensidighed og fortrolighed mellem udsendelse og seer. Man vidste, hvad man kunne vente sig af udsendelsen - man medbragte en forhåndsaccept baseret på erfaringer fra tidligere udsendelser. Denne fortrolighed mellem seer og program - personaliseret i Heide og hans skave grin - blev klogt trukket med ind i det ny program, "Dagens Danmark", således at den nye udsendelse til en begyndelse kunne låne popularitet fra den gamle.

Ikke noget dårligt startgrundlag.

"Dagens Danmark" - Provinsafdelingens nye flagskib

I Aarhus Stiftstidende søndag den 1/3-1981, en uges tid før provinsafdelingens nye magasinprogram "Dagens Danmark" gik i luften første gang, sagde den hovedansvarlige for programmet, Preben Heide: 
Man kan godt sige, at vi simpelthen forsфger at lave bedre TV. Vi har plukket de bedste elementer ud af programmer, der har vist sig at være godt TV.

Det fremgår af interviewet, at de successer, som Heide navnlig tænker på, er "Landet Rundt" og Kanal-udsendelserne. Det nye magasin skal forene det starkt engagerende og dramatiske, som seerne sarligt kender fra Kanalerne, med det mere bredt berettende fra "Landet Rundt".

I foromtaleme prasenteres programmet helt klart som en svendeprøve. Nu skal provinsafdelingen vise, hvad den kan, năr de tekniske forudsætninger for professionel programproduktion er til stede. Og samtidigt demonstrere, at man ikke lader sig opsuge totalt af den hårde, kontante, let aggressive holdning, som har præget Gyngemosens magasiner. "Dagens Danmark" får en puls, som dunker en anelse langsommere, end den gør i København. Som Heide siger det i direkte sammenligning:

Vores stil er en roligere og bredere stil. Mere folkelig.

\section{Godaften og velkommen til "Dagens Danmark"}

Udsendelsen går på. Bag studieværtens højre, magre, lidt duknakkede skikkelse, med al den bekendthed og tillidsvækkende ro, som den udstråler, afslører projektørlyset et rum i halvcirkelfacon. Rummets bageste afgrænsning udgøres af en række rosamalede plader med udsendelsens varemarke - de sammenslyngede D-er - i en lidt mørkere farve.

Helt til venstre i rummet står en rakke stole eller banke tæt besat med afventende mennesker; aftenens publikum. Til højre for dem er der to vinkelsofaer med borde foran - og endelig er der helt ude til højre sat plads af til nogle musikere. I forgrunden forskudt lidt til venstre for midten domineres billedet af en pleksiglasplade med aftenens hovedoverskrifter i i øjnefaldende neonag tige farver og med varieret typografi og punktstørrelse. Til højre for denne plade som forgrundens anden hovedbestandel, står studievarten. 
Dette er "Dagens Danmark" rum. Programmets scene. Til venstre publikum - til høire musikerne - midt $i$, som formidlere og oplysere, som spørgere og professionelle, journalisterne selv med studieværten i spidsen.

Igennem pleksiglaspladen til venstre kan man ane nogle af de hovedagerende i aftenens udsendelse - interviewofferet og spørgeren. Men deres identitet er endnu usikker, fordi hele studielyset ligger pa forgrunden. Der lægges op til spænding, overraskelse, scoop. Preben Heide ser direkte på kameraet. Er i $\emptyset$ jenhøjde med det. P\& den ene side fremstår han altså som den, der hersker over det indviklede tekniske apparat, på den anden side som den, der er på niveau med seeren. Hans opmærksomhed er vendt imod denne seer. Publikum og de agerende er en del af det, som han hersker over. Her fylder studiet noget. Det er - et studie, og lagger først og fremmest op til tough journalistisk professionalisme.

\section{Varsgo' til Benny Aros}

Benny Aros var med til fra starten at lagge stilen. En stil som er bibeholdt, selvom han nu er flyttet til chefstillingen i $\varnothing$ stjyllands Radio.

Hårdt, pågående og velforberedt. Det var parolerne. Intet forlorent kammerateri. Ingen lunkne thepotter eller indforståede fnis. Intervieweren og offeret var fjender, så lange kameraet var på. Og det var dette fjendskab, mere end hvad den interviewede egentlig havde at sige, som skabte den spænding, som Preben Heide talte om fra starten. Det store spørgsmal var ikke, om den interviewede havde ret eller uret. Om han havde noget vasentligt at sige, eller om han blot plaprede. Det spandende var, om han kunne sta for mosten. Om han brфd sammen og tilstod, eller om intervieweren matte give sig.

Således forvandledes interviewet til en gladiatorkamp, hvor medielivet var indsatsen. Sofahjornet blev et farligt sted. En polstret elektrisk stol, hyor intervieweren hele tiden sad med kontakten i hånden. Hvert фjeblik kunne strømmen blive slået til.

P\& den ande side, så fik denne farlighed ikke lov til at brede sig. Det elektriske felt 
i sofahjornet var forsvarligt isoleret og afskærmet. Dels i kraft af det moment af leg eller kappestrid, som pragede selve interviewsituationen. Dels i kraft af, at denne situation blev overvåget af Heide selv. Og endelig i kraft af, den sammenhæeng, som den hermed indgik i. Preben Heide tager over igen.

\section{Ja, der kan siges både for og imod. Det er aftenens kronikør også inde på .....}

Kronikken - eller krøniken, som den undertiden benæevnes - er en rubrik for useriøs alvor. Her udfordrer skiftende kronikører landets mag thavere og undertiden ogs dets borgere.

I en foromtale i Ekstrabladet d. 4/3-1981 bestemmes denne rubrik således:

Som noget helt nyt, har redaktionen bedt en rakke forfattere skrive en satirisk eller bidsk fortælling til programmet, en såkaldt minirevy, hvor der $i$ tekst og billeder fortalles om os allesammen. Den venter redaktionen sig meget af.

I krøniken dyrkes den 'lette' association, ironien og provokationen. Her spiller dagliglivets store og små absurditeter hovedrollen. Krøniken er en slags causeri, og causeriet er en traditionsrig men belastet genre. Den tilhører og dyrkes af de dannede, de bedrevidende. Den kræver, for at lykkes, et overskud og et overblik, som "Dagens Danmark"s kronikører i mange tilfælde har haft vanskeligheder ved at mobilisere. Alt for of te har man blot fortabt sig i pudsigheder. Ladet ironien blive plat og harmløs. Derved får ufarligheden og det spidsborgerlige fnis lov til at dominere. Effekten bliver afspænding og ikke målbevidst kritik. De absurditeter, som udleveres, fastholdes således på en gang som uundgåelige dele af den faktiske virkelighed og som lattervækkende. Kritikken peger kun tilbage på sig selv og sin form. Den fär fniset og ikke ændringen som mål.

Seeren er nu afslappet og opladt. Aftenens andet hovedpunkt kan komme.

Ja det var så aftenens kronikør. Og så har Ann Nissen med et filmhold varet i ...

Reportagen er nok det centrale punkt i programmet. Et helt hold af reportere forbereder og samler stoffet og producerer indslaget. 
Deres kriterier for, hvilke emner som skal behandles, er efter de hidtidige udsendelser at dømme, solidt funderet $\mathrm{i}$ den generelle mediemæssige debat. Man tager emner op, som af den ene eller anden grund i forvejen er under behandling i den skrevne presse eller ætermedierne. Kun ganske undtagelsesvis opsøger man nyhederne selv.

Nyhedværdien er saledes ofte indskrænket til at give en ny eller hidtil underbelyst vinkel på et ellers kendt materiale. Eksempelvis i behandlingen af Cheminovadiskussionen, hvor "Dagens Danmark" fors $\emptyset$ te at formulere medarbejdernes synspunkter, mens andre behandlinger navnlig havde fokuseret pa andre vinkler: naturforkæmpernes, fiskernes eller forvaltningens.

Endnu of tere ligger nyhedsværdien i, at programmet $s \emptyset$ ger at behandle et allerede formuleret tema med en mere ligelig vægtning af yderstandpunkterne. Alle har ifølge "Dagens Danmark" en ret til at blive hørt - såvidt muligt inden for samme snæure tidsramme. Det var også i reportagerne, at billedsiden i "Dagens Danmark" skulle satte sig igennem. Da dette i løbet af kort tid ikke lykkedes tilstrækkelig godt, indsatte man igen de ultrakorte, ugerevyagtige klip, som havde udgjort en så populær del af "Landet Rundt". Sidenhen har praksis været svingende - afhængig af studieværten.

\section{Og så slutter Dagens Danmark med et musikalsk indslag}

Musikken er næsten altid pæn og poleret. Aldrig for fin og aldrig for ra og generelt uophidsende. Markeret underholdning med andre ord. Afslappende og i фvrigt også if $\emptyset$ lge redaktionen den eneste direkte årsag til studiepublikums tilstedeværelse. Som Preben Heide siger i Aarhus Stiftstidende:

Derudover laver vi direkte indslag fra studiet. Med publikum pa. Det er ikke mindst af hensyn til de musikalske indslag, vi inviterer et publikum. Det er meget vanskeligt for kunstnere at fungere ordentligt uden nogen at optræde for.

Også musikken har afvæbningens og indpakningens funktion. Den skal fornøje, og den skal medvirke til at afspænde den atmosfære, som interviewet eller reportagen har opbygget. Den skal gøre vanskeligt fordøjelige problemer lidt mere mavevenli- 
ge. F.eks. I forbindelse med behandlingen af fremmedarbejderproblemet, hvor et tyrkisk orkester som indramning til et dobbeltinterview spillede traditionel tyrkisk musik. Fremmnedarbejderproblemet fik med ét en mere fornøjelig, klart eksotisk side.

1 ovrigt tjener orkesterplatformen - udover som jordforbindelse - ogsa som fremføringssted for klare lokalinteresser. Det er musikere fra Århus, eller musikere, der optræder på lokale scener, som har forrang. Med skyldig hensyntagen til hvad der måtte være til rådighed af folkelige, nationale navne.

\section{Det var sa alt for nu. P\& gensyn naste mandag}

Og så er programmet forbi. Blandet med de egentlige hovedrubrikker er der undertiden sma filmglimt i stil med "Landet Rundt", gasteinterviews, dublering af de faste rubrikker, mere alment kulturoplysende indslag og lignende. Men de centrale brikker i det puslespil, som Dagens Danmark er, er dem, som vi har talt om herover.

\section{Alt var lige godt, når bare det underholdt}

Provinsafdelingen præsenterede programmet som en blanding af elementer, der alle ved tidligere lejligheder havde vist sig at vare godt TV. Dvs. gav højt seertal. "Landet Rundt" var en succes, ligesom Kanaludsendelserne var det. Man har taget, hvad man mente, var disse programmers karakteristiske elementer og har fors $\emptyset \mathrm{gt}$ at tillempe blandingen provinsens specielle, langsommere livsrytme. Den langsommere puls, som Preben Heide talte om.

Og hvad er så blevet resultatet? Hvad er der kommet ud af krydsningen?

Udsendelsen er præget af en række ensvirkende træk. For det forste, så er den nivellerende. Den lader idrætsskader hos unge, gift-skandaler i Nordjylland, Holger Danskes forvitring i Kronborgs kasematter, arbejdsløshed i Nordborg, landbrugets strukturproblemer og kritikken af universiteternes styreform figurere side om side som ensbenavnte, sammenlignelige nyheder. Alt kan behandles og bliver behandlet med samme ambition. Nemlig ambitionen om at ville underholde. Og alt om tales $\mathrm{i}$ 
det samme rolige, uforstyrrelige tonefald.

For det andet: Alle de kanter, de uformidlede brud, de uafrystelige og næsten uhåndterlige problemer, som måtte restere, efter at et enkeltindslag er afsluttet, pakkes ind og afvabnes ved hjælp af den overordnede form. Den rolige puls bliver til en provinsiel og professionelt garneret uanfægtelighed. Det smertelige bliver interessant, det brudfyld te fascinerende, og resten bliver morsomt.

At tale om zendringer, alle holdninger, som emnerne matte indbyde til, forvises systematisk. If ølge "Dagens Danmark" er det danske samfund nok usammenhængende, opbrudt og truet. Men derved er intet at gøre. Sådan er virkeligheden bare.

Programmet er ligescettende. Overfor den almene akvivalent, som hedder seertal bliver alt ensbenæunt. Midler for et højere mal. Ensbenaunte, frit udbyttelige st $\varnothing$ rrelser. $O g$ ved at gennemføre denne omveksling argumenterer journalisterne samtidigt for deres egen nødvendighed. Intet underholdningsindslag, ingen reportage er underholdende nok, hvis ikke gyset lurer under overfladen. Det virkelige livs trusler skal ligne sig selv og dog ikke. De skal nemlig vare under kontrol. Som domptører fremviser Preben Heide og Co. det lunefulde og undertiden farlige hverdagsliv. Og som måbende cirkusgaster underholdes seere og studiepublikum med deres egen angst.

Det er her, at programmets afgørende brugsværdier ligger. Såvel for det publikum, som ser pa, som for de folk, der har lavet og markedsført programmet.

\section{Vi laver TV for købmanden i Alestrup}

I et interview med Claes Kastholm Hansen I Politiken d. 4/10-1981, siger Jacob Nielsen fra provinsafdelingen:

(Købmanden fra Alestrup) er min gennemsnitsseer, hvad underholdning angår. En smăhandlende, den gruppe I landet, der har mest behov for at tage skoene andeligt af en gang imellem, som har en forventning om at blive underholdt på en elskværdig måde for de penge, som et farve-tv har kostet ham. Han er interesseret i samfundet, vil gerne have noget med mening i. Han hører til dem, der er voldsomt skuffet over Socialdemokratiets kulturpolitik, fordi den er blevet mere og mere centralistisk - nej, 
det er ingen Glistrup-mand, han er ikke materiel egoist.

Med k $\phi b$ manden 1 Alestrup i hånden har provinsafdelingen markeret sig 1 konkurrencen med Gyngemosen. I provinsafdelingen kan vi, siger Jacob Nielsen, give folk hvad de vil have. $\mathrm{Og}$ vi kan gøre det lige så professionelt, lige så effektivt og til farre penge.

Sammenkoblingen af joumalisternes ambition om at lave 'bedre' - dvs. teknisk og journalistisk mere perfekt - TV, og provinsafdelingens ambition om at ville konkurrere med moderdyret i Gyngemosen, er resulteret i et hamskifte. Fra mosters flimrende feriefilm i "Landet Rundt" til den glatte, harmoniserende, pseudomondzene overflade i "Dagens Danmark". Legitimationen for dette hamskifte søges i provinsafdelingens opfattelse af, hvad "kunderne" onsker: Afslapning, en anledning til ândeligt talt at smide skoene. Valuta for de 5-7000, som man har investeret $i$ et farve-fjernsyn.

Den virkelige provins er fuld af brud, efterslab og problemer. I den virkelige provins er historien, det forgangne, til stede ikke blot som potteskår i mulden. Den er en del af dagligdagen. Den er - som spor i landskabet, som adfardsformer og

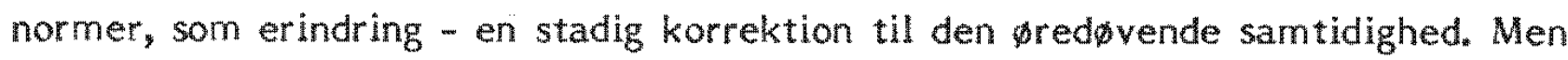
det er ikke denne brudthed, korrektionsmuligheden, som "Dagens Danmark" registrerer. Her forkastes bruddet som noget ubrugeligt. Vel er virkeligheden brudt, men brudtheden forstas kun som splittethed. Som usammenhang. Og ikke som den spanding, den reelt er. Protessionaliseringsinteressen, som bl.a. fik Preben Heide til USA for rigtigt at studere TV, har i virkeligheden varet med til at undertrykke de kritiske muligheder, der var $\mathrm{I}$ "Landet Rundt". Ambitionen er blevet teknisk og popularitetssøgende. Høje seertal giver pote $\mathrm{i}$ argumentationen for at placere et TV 2 i Arhus. Brugen af publikum i studiet er i den henseende typisk. De er der, for at vare objekt for musikerne. Og i takt med at publikum således har narmet sig kameraets linse, er dets virkelige problemer gledet ud af focus.

Den kritik af den socialdemokratiske centralisme, som Jacob Nielsen formulerer i citatet, dakker ikke over reelle decentraliseringsønsker. Hvad man фnsker på Halmstadgade er blot en "alternativ centralisme" - en "positiv" centralisme. I Halmstadgades TV 2 er "en virksomhedsleder ikke automatisk en forurenende 
slyngel" (Gerhard Nielsen, Politiken,. d. 4/10-1981). Der har man realiseret, hvad Erhard Jacobsen har krævet at Gyngemosen tilstræber: En kritik kommenteres altid af den kritiserende i samme udsendelse - eller kritikken droppes.

Jamen, hvorfor får provinsafdelingen så de høje seertal? Hvis den misbruger folk, hvis den manipulerer med deres behov og deres historie, hvorfor kan de så $\mathbf{~ i}^{\circ}$ udsendelserne? Primært fordi provinsafdelingens folk af mange årsager ikke har formået at lave så perfekt TV, som de har ambitioner til. Bevæger reportageholdet sig ude i landet - og det gør det faktisk sommetider - så må kameraet registrere den landskabelige historie på godt og ondt. Fjorde og skove, marker og gårde. Naturens rytme. Vejrets rytme. Imellem betonklodserne på Halmstadgade kan man se bugten og bakkerne p\&̊ Mols. Men folk kan ogs̊ lide udsendelserne, fordi de faktisk generelt har den lidt langsommere puls, som Preben Heide taler om. Og endelig så skyldes en vasentlig del af successen nok, at provinsafdelingen kan trække p\& en temmelig stor goodwill i kraft af sit navn og sin beliggenhed. $1 \mathrm{kraft}$ af, at den - uanset huad den ellers er - ikke er "København", hvad den i øvrigt heller ikke undlader at bemærke, når lejlighed gives.

Provinsafdelingens ledere er agenter for en fremmed centralisme. De forsøger som koloniforvaltere at rane til sig af udørkenens skatte. Skatte, der måske ikke engang har erkendt værdi for de indfødte. Men glasperler og spejle kan ikke for altid byttes for guld. Og selvom ildvand for en tid kan passivisere, sa holder det ikke i laengden.

\section{Den tredje vej}

De foregående sider har været spækkede med bredsider mod Provinsafdelingen, som den tager sig ud i dag. Det kunne måske rejse tvivl om, hvorvidt afdelingen overhovedet er eksistensberettiget i en tid, hvor midlerne til radio og TV er yderst begrænsede. Når man så åbenlyst har tabt provinsopgaven på gulvet, og når man tilsyneladende nærmest er besat af tanken om for enhver pris at vokse op i højde med ophavet og faktisk strømliner enhver tanke herefter, så burde offentligheden maske alvorligt overveje de forslag om en nedlaggelse af afdelingen, som 1981 bragte med sig. 
Tanken kunne have sine tillokkende sider, må vi indrømme. Alligevel ser vi den gerne lagt i mølposen indtil videre. Fra vores synspunkt var selve ideen om en decentralisering af DR nemlig både væsentlig, anvendelig og endog fremsynet. At ideen så på det nærmeste blev kvalt i fødslen på grund af det politiske klima den blev til i, er en anden sag. Det rokker ikke ved, at afdelingen stadig er en gigantisk mulighed for at sprænge nogle af de grænser for TV-mediets funktion, som DR ellers har indpodet $i$ os, som var de givet fra naturens hånd. Provinsafdelingen kan blive en vasentlig kulturel modvegt i en situation, hvor den internationale TVindustris programmer kommer væltende ned fra himlen med budskaber, der næppe har den mest abenlyse eller direkte forbindelse til vores dagligliv og erfaringsverden. Men så skal afdelingen på helt afgørende vis ændre signaler. Sa nytter det ikke, at også Gerhard Nielsen får sit budget til indkøb af udenlandske dåseprogrammer. Så må tingene gribes an forfra.

\section{Provinsen som programgenerator}

Det er muligt at tage provinsen alvorligt programmassigt. Det viser en del fortilfælde. Det er også muligt at få seerne med, hvis kvaliteten er tilstrækkelig god. Serier som "Krigsdøtre" og "Matador", der på fiktionsplanet pa helt centrale punkter tager deres udgangspunkt i provinsen og dens historisk-aktuelle problemflader af varierende karakter, gik for alvor hjem, som det hedder, på de danske TVskarme. Det samme gjorde "En by i provinsen", der i det mindste i sit oplag rummede væsentlige tendenser til en kulegravning af den moderne provinsbys problemsfære. Man kunne også pege på en TVA-produktion som "Portræt af en by", hvor Rolf Jonshøj fik tegnet et så nuanceret billede af Horsens og dens aktuelle sociale og kulturelle problemer, at man i visse øjeblikke nagtede at tro, at dette var en almindelig ongang TV-Aktuelt.

\section{Drehn-Knudsens bonder og fiskere}

Skoleeksemplet på produktioner, der fik fat i provinslivets rødder og som formåde at frembringe TV-oplevelser, der klart skilte sig ud fra hverdagskosten ved skærmen, er dog nok stadig Erik Drehn-Knudsens udsendelsesserier om "Bønderne" 
og "Arøsund". De havde alle klar karakter af eksperiment og har givetvis varet dyre bl.a. fordi man tillod sig en optagelsesrytme, der ikke alene var bestemt af TV-folkets belastede tidsskemaer, men som forholdt sig til noget sa fundamentalt som årstidernes vekslen, dagliglivets sendrægtige funktioner fra staldudmugning til brugsindkøbet o.l. Det er måske - kvantitativt set - dårlig TV-økonomi, men det er påsin vis selve forudsætningen for ordentligt TV, at man anbringer sig solidt inden for den horisont, produktionen påberåber sig som ramme. "På TV tager tingene den tid, de tager", har Erik Balling sagt. Og når selv Preben Heide frejdigt har erklæret og altså også erkendt, "at provinsens puls slår langsommere...." så må det være til at indse, at det ikke kan og heller ikke skal være Provinsafdelingens opgave at konkurrere énsidigt på lavpris og ren masseproduktion, for netop den burde tage sig tid.

\section{Provinsen som udfordring}

De næunte eksempler viser alle, at det er muligt at lave gode programmer med provinslivet som emne og udgangspunkt. Tankevakkende nok er ingen af dem produceret i Århus, og selvom "Landet Rundt" rummede ansatser i samme retning, så rokker det ikke ved, at det er København, som helt afgjort har taget teten i de spæde fors $\phi g$, vi har set pa at lave ordentligt TV med provinsen som scene og indhold. De bedste af disse programmer bidrager afgørende til den nødvendige nedbrydelse af myten om, at det er i centrene, livet leves... Livet leves som bekendt overalt i Danmark, men byder sig måske ikke til på samme måde overalt rent TV-mæssigt. At befri provinsen programmæssigt kræver indsigt, og indsigt er igen produkt af flid, viden, arbejde og ressourcer. Og det er den udfordring, Provinsafdelingen hidtil har ladet ligge, og det er der - igen - grund til at opholde sig ved.

\section{Provinsen som udfordring eller hvad er der galt?}

Skal TV-mediet opnå nogen kulturel brugsværdi for andre end politikerne, må man lære at forbinde det med og samtidig respektere de erfaringer og den erfaringsverden, individer, grupper eller klasser lever I og med. Farer man frem på anden måde, 
forvandles mediet til et instrument, der nok kan passivisere folk, satte dem pa plads, handle med dem, men ikke - selv i mindste mal - befri dem. Ud fra den positive betragtning er der god brug for TV i provinsen, hvor de senere årtiers brutale generaliserende udviklingsrytme har bragt mangt og mange i klemme. Spфrgsmalet er vel, om nogen tidligere generation i Danmark har oplevet sa hovedkuls og undertiden også hovedløse forandringer som den nulevende. At denne udvikling har haft sine svære omkostninger og afsat sine brud i bevidstheden rundt omkring, ved enhver, der ikke er fuldtids optaget på den teknokratiske legeplads. Det er disse brud, det er Provinsafdelingens opgave at producere programmer om gerne både fiktive og journalistiske. Gerne både alvorlige og underholdende. Det er afdelingens forbandede pligt seriøst at behandle de udviklingssår, som er opstået, dvs. fors $\phi$ ge at gøre sig til et forum, hvor man alvorligt arbejder på at skabe indblik I de omkostninger, den grasserende udvikling har påført provinsen og dens beboere, og hvor man sagligt skaber diskussion om selve udviklingsbegrebets mangfoldige sider og aspekter. Det er imidlertid en risikobetonet proces. Man risikerer nemlig at lægge sig ud med magtcentrene, de lokale såvel som det centrale, når man borer i udviklingens bagsider. Man risikerer at stille politikerne og teknokraterne $i$ et dårligt lys, og dermed risikerer man igen, at de slår pengekassen i. Den risiko bør man tage. Ellers er man p̊̊ forhånd reduceret til hyggeonkel og affirmativ budstik.

\section{Provinsafdelingen oven vande}

Provinsafdelingen kom til $\mathrm{i}$ en tid, hvor udviklingen nåede uanede højder $\mathrm{i}$ det danske samfund. Til en vis grad er det rimeligt at påpege, at behovet for en sådan afdeling netop blev akut $i$ det selvsarnme tidsrum, hvor den så dagens lys. Det er et overordentligt stærkt grundlag at få forærende. En udnyttelse af denne - i så mange henseender - gunstige situation forudsætter imidlertid, at afdelingen lægger roret hårdt om, for den sejler i øjeblikket den forkerte vej. Tanken om, at provinsen og et TV 2 skulle være to sider af samme sag, må opgives. Man kan ikke b̊̊de vokse $\mathrm{i}$ højden og bredden på denne måde, når midlerne er knappe, og når det er de selvsamme medarbejdere, der dagligt skal forene to sa forskellige udviklingsretninger $\mathrm{i}$ deres hoveder og $\mathrm{I}$ deres arbejde. Man skal ikke satse pa kvantitet og lavpris - selvom guderne skal vide, at der kan spares I DR. Man skal satse på en anstændig effektivitet, men $\mathrm{i} \phi v \mathrm{vrigt}$ forsфge at overbevise om, at provinsen stiller 
særlige krav, og at programmæssig kvalitet er forudsætningen, hvis man skal fastholde seerne i den tiltagende konkurrence fra udenlandsk TV. Medarbejderne mâ nægte at underlægge sig det professionalismebegreb, de som en tom teknisk abstraktion har taget i arv fra København og ikke mindst udenlandsk TVproduktion. De må eksperimentere sig frem til, hvad professionalisme på dette område er, og dertil $\mathrm{ma}$ de betinge sig den nødvendige tid og de fornødne researchmuligheder. Og skal det endelig skares ud i pap, så lad os da gøre det således:

Provinsafdelingens medarbejdere skal ud i provinsen. De skal væk fra studiernes plexiglasverden, som homogeniserer alle personer og problemer til ukendelighed, fordi de reducerer enhver sanselig konkret rest af autencitet af miljømæssig, regional og historisk art bort. De skal betjene sig af teknikken, men ikke tjene den, for som det er i dag, stiller det tekniske apparat og medarbejdernes teknikforgabelse sig ganske enkelt i vejen for den substans, der skal formidles. Og selv den lange og svære proces, hvis mal er at bringe medarbejdernes bevisthed i højde med den krævende og indviklede provins- og udviklingsproblematik, som er opgaven, begynder ikke i teknikken eller i overvejelser over den - men derude, hvor både kragerne og tankerne stadig vender.

Per Jauert, Jan Mølgaard og Mogens Schmidt er ansat ved Nordisk Institut, Aarhus Universitet, Keld Vorup Sørensen ved Rasmus Rask Instituttet for Lingvistik, Odense Universitet. 


\section{REGIONALRADIOEN: PROVINSIEL OG BUREAUKRATISK}

\section{Af Lars Qvortrup}

\section{Som man spsir får man svar}

1980 blev der offentliggjort en undersøgelse af forholdet mellem regionalradio og lokalsamfund, som blev foretaget af DR og fremlagt i tre forskningsrapporter: Den forste rapport af Anker Brink Lund handlede om regionalradioen og informationsbehov. Den anden af Erik Nordahl Svendsen handlede om lytternes forventninger til regionalradioen. Og den tredje, af Lund, Svendsen og Olga Linné sammenfattede og supplerede de to forste.

I Anker Brink Lunds rapport leveres undersøgelsens baggrund. Den besvarer sporgsmalene om, hvilke informationsbehov der findes I lokalsamfundet og hvordan regionalradioeme generelt imødekommer disse behov. Dette gør den pa baggrund af en omfattende lytterunder $\$$ gelse (om lytternes lytning til regionalradioerne, deres op attelse af regionalradioernes opgaver, deres programvurdering og deres informationsbehov), og på baggrund af en kvantitativ indholdsanalyse.

Hvad angår analysen af informationsbehovene er det unders $\emptyset$ gelsens styrke, at den ikke slutter sig til informationsbehovene ud fra en registrering af, hvad folk allerede lytter til. Konsekvensen af en sadan fremgangsmade er jo, at medierne selv får lov til at definere de behov, som de skal opfylde. Den spørger heller ikke abstrakt om, hvad der $\mathrm{i}$ almindelighed forekommer vigtigt for lytterne. En sadan sporgeform appellerer kun til den konforme fantasi; den registrerer alene de allerede erkendte behov og ikke de skjulte - og maske vigtigere - informationsbehov. Derimod spørger Anker Brink Lunds analyse konkret, ud fra fem spørgsmal: Har den udspurgte behov for information om bornehaver/skoleforhold/organiserede fritidsaktiviteter/arbejdsløshed/forretningslukninger?

Svagheden ved analysen er, at den ikke - i det her foreliggende tilfalde - foretages ud fra en teori, hvilket i dette tilfalde ville have sagt et eksplicit, videnskabeligt argumenteret begreb om lokalsamfundet. Det betyder, at de fem refererede 